\title{
Reflections on Local Colleges and Universities' Convergence from the Perspective of the Comparative Advantage Theory
}

\author{
Lin Yun ${ }^{1}$ \\ College of Public Administration \\ Yunnan University of Finance and Economics \\ Kunming, China, 650021 \\ E-mail:584269287@QQ.com
}

\author{
Wang Hong ${ }^{3}$ \\ International Education Exchange Institute \\ Yunnan University of Finance and Economics \\ Kunming, China, 650021
}

\author{
Zhu $\mathrm{Jie}^{2}$ \\ Research Department \\ Yunnan University of Finance and Economics \\ Kunming, China, 650021
}

\begin{abstract}
From the perspective of comparative advantage theory, the convergence of local colleges and universities is a process that they look for development against their endowments, which caused by the external institutions. It is mainly manifested in the following three aspects: the converge of discipline, lacking of core competitiveness; the convergence of specialty, lacking of viable ability; the convergence of training model, lacking of differences. One of the basic ways for local colleges and universities is to look for developing on their differences and endowments; another way for the local government is to try its best to reform the evaluation mechanisms and fiscal funding system, and set up information platform to protect their comparative advantage and leading them developing healthily.
\end{abstract}

Keywords-comparative advantage theory; local colleges and universities; convergence; reflections

\section{A BRIEF INTRODUCTION TO THE THEORY of COMPARATIVE ADVANTAGE}

At the early time of 1776 , Adam Smith made a conclusion that the division of labor will make workforce more skilled, social labor productivity higher, national treasure richer, in his research of An Inquiry into the Nature and Causes of the Wealth of Nations. And the principle of the division is that the absolute cost advantage or absolute interest, which means, each person should specialize in the production of his most advantageous fields according to their own endowment and gift, in order to exchange their benefits with each other. This process is beneficial to both sides. Smith further analogized this principle to the division of labor between country and country, which is a situation that if a country's production cost is lower than another country due to its natural conditions or sources, so that this country will enjoy absolute advantage and a less cost in the production process than another country, which is without those advantage but in need of these products. This is formed between the two countries, which of the two countries are beneficial. [1] Thus, the Smith brought the principle of absolute advantage into the sight of people, creating a source of comparative advantage theory. However, the principle of absolute advantage cannot explain the participation of the countries without absolute advantage in international trade.

How can we explain the participation of countries without the absolute advantage in international trade? David Ricardo answered this question in 1817 in the book of Political Economics and Taxation Principle by referring to "labor value theory", which is regarded as the basis of the theory of comparative advantage. In the view of David Ricardo, the cause of the international trade is not about the absolute difference but the relative difference in cost. Although a country is at a disadvantage position in two kinds of products' production, as long as the different degree of adverse exists, there is always a product having a less disadvantage, which has relative advantage. If a country with the relative advantages starts the specialization and the international exchange of products for trade, both sides can also benefit from the exchange.[2] By this way, both sides can break through the limitations of Smith's theory of absolute advantage.

However, Ricardo's theory of comparative advantage does not point out where is the source of comparative advantage coming from. The study of Swedish economist Eli Heckscher and his student Ohlin indicates that the differences between the relative scarcities of countries' production factors are the essential conditions of cost difference, so of the international trade. [3] In their view, abundance differences in the structure of factor endowment and element level, is the source of comparative advantage. Therefore, countries can produce and export products with advantages according the differences between their endowment structures of production factors, and imports products without comparative advantage according to its endowment structure. Obviously, the difference of factors and the abundance degree of the two core concepts is the key factor of the theory of comparative advantage. 
With the development of economic and social development, the theory of comparative advantage has become into analysis methods and tools of industrial development from the interpretation of trade reason theory, and become into the guiding principles of economic development of some developing countries to formulate development strategy of the important basis. Yifu Lin, a famous economist in China used the theory of comparative advantage to economic development, and put forward the development strategy of comparative advantage. Therefore, the development of a country's economy must be based on its own factor endowment structure and the formation of the comparative advantage, so as to improve the viability of enterprises, have the core competition, achieve capital surplus, enhance the factor endowment structure; and new factor endowment structure will bring a new round of industrial upgrading and technological progress, in a result to keep the sustainable development of economy. The principle of comparative advantage between different countries is not only applicable to the economy, is also applicable for different enterprises in different regions within a country. [4]

\section{InSPECTION OF THE CONVERGENCE OF LOCAL COLlEGES AND UNIVERSITIES FROM THE PERSPECTIVE OF THE COMPARATIVE THEORY OF ADVANTAGE}

From the two core concepts of comparative advantage theory, namely the difference of endowment structure elements and the level of endowments' abundance. It emphasizes that international trade and economic development should be both in accordance with its factor endowment structure in their industrial production, in order to form the optimal industrial structure. Once betrays its own endowment structure, blindly take to catch up with the industrial structure and set up their own thinking, factor endowments do not have the advantage, will only lead to economic development lag. In recent years, local higher education in our country has been an unprecedented development, but due to blindly "big and complete" and "upgraded heat", the local colleges and universities appeared three aspects of school type, professional setting, personnel training mode against the convergence of its endowment structure.

\section{A. Convergence of type}

With the reform of China's economic system, the higher education developed rapidly. In 1997, the number of colleges and universities was 1020 , the number of undergraduate students was 579.7 thousand, and the junior college education was420.7 thousand, which break out 1000 thousand; In 2014, there are 2529 regular college and university (including 283 independent college ) , undergraduate and junior college enrolled 7214 thousand people. For more than ten years, the number of colleges and universities turned nearly 1.5 times, the number of college enrollment has more than 7 times. (1) According to Professor Martin Tero's distinguished standard of higher education, the higher education in our country has reached the intermediate stage of popularization. Local colleges and universities have been developing rapidly both in quantity and scale. In order to survive in the market effectively, the local colleges and universities are competing to strive for "Large and Completed". The originally local comprehensive university seeks to emulate to Tsinghua University and Peking University; the originally one subjected university seeks to turn to comprehensive university. Major colleges and universities are trying to improve their education level and constantly strive to imitate blindly in order to upgrade. And this blind hardworking is disregarding the endowment structure, which is deviating from the local development track, and also out of the touch of local economic and social development. The following consequence is invalid of college's function of serving the local economic development, more importantly, leading to homogenization of the serious employment problem of talent cultivation, also leading to the same type and level of the universities, tuning out losing of features.

\section{B. Convergence of specialty settings}

Local colleges and universities have set so many same and popular specialties demanded by the market without considering teaching conditions and teaching resources, which results in the convergence of specialty. For example, accounting is a popular specialty in china with its high employment rate. Therefore, many local colleges and universities have set up accounting in their discipline .In Yunnan province, There are 22 colleges, 7 independent colleges, 38 schools of higher vocational colleges. And there are 39 colleges which have set accounting or financial accounting. A scholar called He-an from Western Normal University have done a research about the convergence of specialty in Sichun province. And the results show that there are professional distribution of more than 15 schools in a total of 16 specialties in Sichun province, science and computer technology, law and English are the most and largest enrollment. In addition, such as management, economics and science of law are the most convergent.[5] MyCOS Institute's research reports of "Chinese college students employment" in the year of 2010,2011 and 2012 showed that such as law, computer and English which were once popular in the three years are warned with red and yellow card for their low employment rate. As can be seen, the convergence of specialty setting in local colleges and universities can not only achieve the optimal allocation of educational resources, but also lead to serious structural unemployment.

\section{Convergence of talent training mode}

In 1998, Minister of Education in China issued a document called " opinions on deepening the teaching reform, to cultivate high quality talents for twenty-first Century" which defined that "talent training mode" is a way to help student to construct knowledge, cultivate abilities and the structure of quality, which stipulates the students characteristics, reflects the thought and concept of education. "Talent training mode" can realize what kind of people should be cultivated "and" how to cultivate individuals ". With the convergence of local colleges and universities' types and specialty setting, their talent training modes are convergent at the same time. After the expansion of higher education, some local colleges and universities changed the single mode of training academic talents according to the demand of the talent market's characteristics. Fallowing by this, the training mode of compound talents, training mode of applied talents, international talents cultivation and creative talent cultivation 
mode have appeared in various collages and universities' training programs, which attracted a new round of homogenization of talent cultivation. Obviously, this doesn't match diversified talent demand of the development of regional economic, coincide diversity of the individual needs in mass education, and then it's bound to hinder the development of economic and society, even the cultivation of diversified talent.

\section{THE SOLUTION TO CONVERGENCE IN LOCAL COLLEGES: FOLLOW THE COMPARATIVE ADVANTAGE}

The excessive convergence in local colleges is a developing process of college's disciplines, specialties and personnel training mode, which violates its natural endowment by external environment. It caused by both internal factors and external factors. In the view of two reasons of convergence (the local colleges and local government), the solution to convergence can be found.

\section{A. Follow the comparative advantage and establish the viability}

Due to the highly centralized management system and resource allocation mechanism, local colleges lack of autonomy and viability. So local colleges and universities keep seeking the legitimacy of the existence and higher perfection, which leads convergence of school type, major setting, and talent training type. According to the theory of comparative advantage, a lack of viability of the enterprise is unable to get promising profit and survive in the market. Similarly, local colleges without viability are not able to survive in a market economy. So cultivating local colleges viability is the key point to solve convergence.

Local university itself should set the target in running colleges, subject category, diversified talent training mode based on its natural endowment. The natural endowment of college refers to material conditions of running schools, faculty structure, and scientific research accumulation, characteristic of campus culture and so on. Different university has different endowments and also abundance degree of endowments is different. Take local business as an example, it is abundant endowment in major economic and management disciplines. Obviously, economic university has advantages of above aspects in talent training and scientific research and social services. Thus, each university should run school based on its own comparative advantage in order to gain more educational resource in the competitive marketing, which can optimize its ability. Then the benign cycle can realize the ability of local colleges.

\section{B. Preserve the comparative advantage and develop in healthy and ordered way}

Local government should establish a market-oriented education resources allocation mechanism, extend the power of the local colleges to different directions, reform evaluation mechanism and funding mechanism, set up information platform and maintain its own respective advantages so as to ensure its healthy and orderly development.

First of all, the local government should reform their own evaluation mechanism dominated by themselves, introducing the third party appraisal institution. Classification evaluation should be implemented to ensure evaluate efficiently and publish the evaluation result to the society to achieve "peer competition, superior win, the inferior out". Secondly, local government should reform the higher education funding mechanism in order to maintain the advantages of local colleges, which is helpful for their healthy development based on comparative advantage. Local governments need to take the combination of "foundation grants + performance funding" funding mechanism.

Basic funding should base on the average cultivation cost and the total number of students in order to guarantee the basic teaching operation and development of local colleges. But the purpose of performance funding is to improve the level of local university and avoid convergence development, including teaching quality evaluation funding, subject competitive grants and individual merit special appropriation fund of higher education, which will stimulate them to comply with theory of comparative advantages based on its own endowment [6]. Lastly, local government should set up information platform, establish database information database construction of academic disciplines and talents demanding, give full play to the role of the information collection and transmission, and publish provincial discipline professional domain information and talents demanding to society. Then it can guide the local colleges to cultivate talents according to their own endowment and market demands. It can not only maintain its advantages but also reduce blindness in terms of discipline construction and talent cultivation. Namely it can reduce "homogeneity" talent cultivation and talent of the structural unemployment. At same time, convergence can be avoided.

\section{REFERENCES}

[1] Adam - Smith, An inquiry to the nature and causes of the wealth of nations. Beijing: Commercial Press, 1996.

[2] Guan Gong, International Trade Theory, Wuhan University Press, 2000.

[3] $\mathrm{Li}$ Huiwen, dynamic nature of the modern theory of comparative advantage ,Economic Review, 2004, (1), 42-47.

[4] Lin Yifu, Sun Xifang ,Comparative Advantage Theory of Economic Development Strategy, International Economic Review, 2003, (11-12), 12-18.

[5] He An, DU Xue Yuan, Specialties College of similar problems ,Educational Research, Tsinghua University, 2004, (10), 93-97.

[6] Zeng Yalan, From the perspective of educational resource fair financial allocation mechanism places of higher education ,Higher Education and Economy, 2011, (9), 59-64. 